\title{
MAKNA CINTA DALAM LIRIK LAGU AUT BOI NIAN \\ SOUNDTRACK FILM TOBA DREAMS \\ (Analisis Semiotika Ferdinan De Saussure)
}

\author{
Ilona Vicenovie Oisina Situmeang \\ Universitas Persada Indonesia YAI \\ Pascasarjana Ilmu Komunikasi \\ ilonaoisina@yahoo.com
}

Diterima : 02 November 2019; Review : 06 Februari 2020; Direvisi Author : 21 januari 2020; Terbit : 14 Februari 2020

\begin{abstract}
Generally the song lyrics have their own meaning that is characteristic of the song. Song lyrics there are themed love, family, expressing the feeling of pleasure and sadness of the creator. Likewise, the song lyrics from Aut Boi Nian used in the Toba Dreams movie soundtrack tell about love that is opposed by families due to economic reasons. This study uses Ferdinan De Saussure's semiotic analysis of the lyrics contained in the song. Using the constructivist paradigm with a qualitative research approach and the nature of descriptive research. The results in this study give meaning to the lyrics related to Signifier and signified, Form and content, Langue (language) and parole (speech $/$ utterance), Synchronic (synchronous) and diachronic (diachronic)), Syntagmatic (syntagmatic) and associative (paradigmatic).
\end{abstract}

Keyword: Meaning of Love, Song Lyrics, Aut Boi Nian, Semiotics, Semiotics of Ferdinan De Saussure.

\section{PENDAHULUAN}

Dalam kehidupan ini manusia tidak lepas dengan namanya cinta. Sebagai sebuah konsep, cinta sedemikian abstraknya sehingga sulit untuk didekati secara ilmiah. Menurut Robert Sternberg (1987), yang telah berusaha untuk menjabarkan cinta dalam konteks hubungan antara dua orang. Menurut Sternberg (1987), cinta adalah sebuah kisah, kisah yang ditulis oleh setiap orang. Kisah tersebut merefleksikan kepribadian, minat dan perasaan seseorang terhadap suatu hubungan. Kisah pada setiap orang berasal dari " skenario" yang sudah dikenalnya, apakah dari orang tua, pengalaman, cerita dan sebagainya. Kisah ini biasanya mempengaruhi orang bagaimana ia bersikap dan bertindak dalam sebuah hubungan.

Orang-orang yang sedang jatuh cinta mempunyai kadar cinta yang berbeda-beda, ada yang sangat intim dan mesra, tetapi tidak jarang terlihat pasangan tersebut sering bertengkar dan tidak cocok dalam hal-hal tertentu bahkan ada yang bercerai walaupun sudah menikah. Perbedaan kadar cinta ini mempunyai 
banyak faktor penyebab, salah satu diantaranya karena adanya pengaruh dari tipe kepribadian. Kepribadian memang bersifat unik, sehingga tidak ada satu orangpun yang sama persis dengan orang yang lain, meski mereka terlahir kembar satu telur. Memang ada jutaan variasi kepribadian. Menurut Hartman (2013) kepribadian setiap orang dapat digolongkan menurut motif dasar, kebutuhan dan keinginan yang cenderung stabil sepanjang hayat. Di pandang dari sudut perbedaan motif dasar, kebutuhan dan keinginan maka setiap orang dapat digolongkan kedalam tipe kepribadian merah, biru, putih dan kuning.

Namun tidak sedikit orang yang sedang jatuh cinta mengalami banyak hambatan sehingga walaupun kadar cintanya yang sangat intim jarang sekali yang bisa disatukan karena hambatan tersebut. Hambatan tersebut antara lain karena adanya perbedaan agama, di Indonesia mengakui adanya agama dan kepercayaan yang berbeda-beda, namun pemerintahan belum mengizinkan adanya perbedaan agama dan kepercayaan ini untuk menikah. Selain itu juga ada dikarenakan perekonomian keluarga yang tidak seimbangan diantara dua orang yang sedang memadu kasih, sehingga walau bagaimanapun keintiman hubungan yang telah terjalin susah untuk bersatu.

Kebiasaan yang masih dijunjung tinggi oleh masyarakat Indonesia dari semua suku adalah menghargai pendapat orang tua dalam melanjutkan sebuah hubungan, sebagian besar akan berfikir jika tidak direstui sebuah hubungan ada dampak yang tidak baik untuk kedepannya, sehingga pendapat dan restui dari orang tua sangat menentukan suatu hubungan percintaan menuju pada hubungan yang lebih serius (pernikahan). Sama halnya dengan suku Batak. Restu dari orang tua menjadi alaan utama yang harus dipertimbangkan sebelum melangkah kepada pernikahan. Kebiasaan yang menjadi khas dari masyarakat Batak jika mendapat larangan dikarenakan berbagai hambatan dituangkan dalam lirik lagu.

Sama halnya dengan lirik lagu Aut Boi Nian yang merupakan soundtrack Film Toba Dreams merupakan curahan hati dari sepasang kekasih yang tidak mendapatkan restu dari orangtuanya karena perbedaan status sosial ekonomi keluarga dan berbeda budaya dan agama sehingga ada pertentangan untuk bersatu. Karena restu dari orang tua merupakan sesuatu yang masih dijunjung tinggi dalam masyarakat Batak, sehingga memilih orang tuanya dan 
meninggalkan kekasihnya. Keinginan orang tua mendapatkan pasangan yang sebanding status ekonominya dan diturutin oleh anak perempuannya. Namun pasangannya merasa menjadi suatu tantangan baginya sehingga harus kerja keras untuk medapatkan restu dari calon mertuanya.

Kejadian ini banyak sekali dihadapi oleh sepasang kekasih dari berbagai suku yang ada di Indonesia, sehingga saat lagu Aut Boi Nian ini diciptakan oleh Wervin Panggabean dan diiringi oleh musik Viky Sianipar. Viky Sianipar merupakan salah seorang penyanyi dan komponis bersuku Batak Toba, yang mampu memainkan berbagai alat musik modern dan tradisional. Berkarier di dunia musik sejak tahun 2002, banyak lagu-lagu Batak yang diaransemen dengan Viky Sianipar digemari oleh kaum muda karena musiknya lebih modern namun tidak meninggalkan khas dari Batak Toba.

Musik menurut Rachmawati, 2001 berkaitan erat dengan setting sosial kemasyarakatan dan gejala khas akibat interaksi sosial dimana lirik lagu menjadi penunjang dalam musik tersebut dalam menjembatani isu-isu sosial yang terjadi”. Salah satu hal terpenting dalam sebuah musik adalah keberadaan lirik lagunya, karena melalui lirik lagu, pencipta lagu ingin menyampaikan pesan yang merupakan pengekspresian dirinya terhadap fenomena-fenomena yang terjadi didunia sekitar, dimana dia berinteraksi didalamnya.

Lirik lagu dalam musik yang sebagaimana bahasa, dapat menjadi sarana atau media komunikasi untuk mencerminkan realitas sosial yang beredar dalam masyarakat. Lirik lagu dapat pula sebagai sarana untuk sosialisasi dan pelestarian terhadap suatu sikap atau nilai. Oleh karena itu, ketika sebuah lirik lagu diaransir dan diperdengarkan kepada khalayak juga mempunyai tanggung jawab yang besaratas tersebar luasnya sebuah keyakinan, nilai-nilai, bahkan prasangka tertentu.(Settianingsih dan Atmadi, 2003) Sama hal nya dengan lirik lagu Aut Boi Nian dengan musik Viky Sianipar menimbulkan ketertarikan bagi banyak orang yang mendengarkannya dan menyukai lagu tersebut. Tidak hanya yang mengalami nasib yang sama tetapi juga suka mendengarkan aramsemen dan liriknya yang sangat puitis. Tidak lama setelah lagu itu diciptakan langsung dijadikan salah satu soundtrack pada film Toba Dreams yang diadopsi dari novel Toba Dreams karangan TB Silalahi.

Lirik lagu dalam musik yang sebagaimana bahasa, dapat menjadi sarana 
atau media komunikasi untuk mencerminkan realitas sosial yang beredar dalam masyarakat. Lirik lagu dapat pula sebagai sarana untuk sosialisasi dan pelestarian terhadap suatu sikap atau nilai. Oleh karena itu, ketika sebuah lirik lagu diaransir dan diperdengarkan kepada khalayak juga mempunyai tanggung jawab yang besaratas tersebar luasnya sebuah keyakinan, nilai-nilai, bahkan prasangka tertentu.(Settianingsih dan Atmadi, 2003:8).

Film Toba Dreams merupakan salah satu film yang menceritakan percintaan dari sepasang kekasih yang berbeda status sosial, agama dan budaya, Wanita yang berdarah Jawa ningrat yang kaya raya, tinggal di Jakarta dan membuat wanita ini mulai meninggalkan adat istiadat keluarganya. Hingga akhirnya dia bertemu dengan lelaki yang bersal dari Balige dan menjalin hubungan cinta. Kisah percintaan ini bermula dan berujung di keindahan Balige di Danau Toba, namun melewati berbagai tantangan dan hambatan untuk bersatu.

Dari keindahan lirik lagu Aut Boi Nian muncullah ketertarikan penulis untuk memberikan makna cinta yang terdapat dalam setiap lirik lagu tersebut dengan menggunakan analisis semiotika Ferdinand De Saussure

\section{Fokus Penelitian}

Dalam penelitian ini yang menjadi pertanyaan penelitian adalah: "Bagaimana Makna Cinta Dalam Lirik Lagu Aut Boi Nian (Soundtrack Film Toba Dreams) dengan menggunakan Analisis Semiotika Ferdinand De Saussure?

\section{Tujuan Penelitian}

Tujuan Penelitian dalam penelitian ini adalah: Untuk mengetahui Makna Cinta Dalam Lirik Lagu Aut Boi Nian (Sountrack Film Toba Dreams) dengan menggunakan Analisis Semiotika Ferdinand De Saussure.

\section{METODOLOGI PENELITIAN}

\section{Semiologi Ferdinand De Saussure}

Menurut Ferdinand De Saussure bahasa dipelajari sebagai sistem tanda. Tanda, bagi Sasussure, adalah objek fisik yang memiliki makna, atau kalau menggunakan istilah milik Saussure, sebuah tanda teridiri dari penanda (signifer) dan petanda (signified). Hal yang sangat penting dalam kajian Saussure tentang tanda linguistik adalah sifat arbiter yang mengaitkan penanda dan petanda (Zaimar, 2005).

Sistem tanda sangat diperlukan dalam semiologi. Ferdinand De Saussure 
mengemukakan adanya dua ciri tanda bahas yang sangat mendasar.Tanda bahasa bersifat arbiter (semena), artinya tidak ada hubungan atau ikatan tertentu antara penanda dan petandanya. Yang dimaksudkan dengan semena disini adalah tidak ada alasan tertentu mengapa konsep "saudara perempuan" dalam bahasa Prancis, mempunyai penanda seour. Itulah sebabnya mengapa konsep yang sama dikemukakan secara berbeda-beda dalam bahasa yang berbeda-beda. Ini tidak berarti bahwa setiap individu bebas menentukan sendiri tanda bahasa, karena bahasa merupakan konvensi antara anggota masyarakat.

Penanda bersifat linier, karena pada hakekatnya, penanda bersifat auditif, jadi ia berlangsung dalam waktu tertentu. Seseorang tidak menampilkan imaji bunyi sekaligus, melainkan secara berurutan. Selain itu, secara garis besar, prinsipprinsip linguistik Saussure dapat disederhanakan kedalam butir-butrir pemahaman sebagai berikut:

1. Bahasa adalah sebuah fakta sosial, sebagai fakta sosial, bahasa laten, ia terutama bukanlah gejala permukaan, melainkan sebagai kaidah yang menentukan gejala permukaan, melainkan yang disebut sebagai langue. Langue termanifestasikan sebagai parole, yakni tindakan berbahasa atau tuturan secara individual.

2. Bahasa adalah suatu sistem tau struktur tanda-tanda. Karena itu, bahasa mempunyai satuan-satuan yang bertingkat-tingkat, mulai dari fenom, morfem, kalimat, hingga wacana.

Unsur dalam setiap tingkatan tersebut saling menjalin melalui cara tertentu yang disebut dengan hubungan paradigmatik dan sintagmatik. Relasi atau hubungan antar unsur dan tingkatan itulah yang sesungguhnya membangung suatu bahasa, relasi menentukan nilai, makna, pengertian dari setiap unsur dalam bangunan bahasa secara keseluruhan.

Bahasa hanya dapat dikaji melalui suatu pendekatan sinkronik, yakni pengkajian bahasa yang membatasi fenomena bahasa pada satu waktu tertentu, tidak meninjau bahasa dalam perkembangannya dari waktu ke waktu (diakonis).

Signifier atau penanda adalah gambaran fisik nyata dari tanda ketika kita menerimanya, misalnya: coretan pada kertas atau suara di udara. Sedangkan signified (petanda) adalah konsep mental yang mengacu pada gambaran fisik nyata dari tanda. Petanda (signified) adalah makna yang terungkap melaui konsep, 
fungsi dan atau relasi antara petanda dan penanda berdasarkan konvensi.

Menurut de Saussure, bahasa (langue) memiliki dua aspek, yakni aspek langgue, yakni sistem abstrak yang secara kolektif diketahui dan disadari oleh suatu masyarakat dan menjadi panduan bagi praktik berbahasa, dan aspek parole yakni praktik berbahasa di dalam kehidupan masyarakat. Dalam analisis atau bahasa harus selalu dibedakan kedua aspek itu. Dalam kenyataan kehidupan berbahasa, langue merupakan prinsip-prinsip supraindividual yang mengarahkan parole.

Ada lima pandangan Saussure yang terkenal yang disebut elemen makna milik Saussure, yaitu:

1. Signifier (penanda) dan signified (petanda)

Signifiant dan signifie Ferdinand de Saussure mengemukakan teori bahwa setiap tanda atau tanda linguistik (signe atau singe lingustique) dibentuk oleh dua buah komponen yang tidak terpisahkan, yaitu komponen signifiant dan komponen signifie. Yang diimaksud signifiant adalah citra bunyi atau kesan psikologis yang timbul dalam pikiran kita. Signifie adalah pengertian atau kesan makna yang ada dalam pikiran kita. Ada yang menyamakan signe itu sama dengan kata, signifie sama dengan 'makna'; dan signifiant sama dengan bunyi bahasa dalam bentuk urutan fonem-fonem tertentu. Hubungan antara signifiant dengan signifie sangat erat, karena keduanya merupakan kesatuan yang tidak dapat dipisahkan. Dengan kata lain, 'petanda' adalah aspek material dari bahasa, apa yang dikatakan atau didengar dan apa yang ditulis atau dibaca. Singkatnya, penanda adalah yang menandai, petanda adalah yang ditandai.

2. Form (bentuk) dan content (isi)

Form adalah aturan penggunaan bahasa, sedangkan content merupakan koleksi unsur dari sistem. Istilah form (bentuk) dan content (isi) ini diistilahkan dengan expression dan content, sesuatu yang berjudul bunyi dan yang lain berwujud ide. (Lechte, 2001) istilah form dan content ini dengan expression dan content, satu berwujud bunyi dan yang lain berwujud idea. Saussure membandingkan form dan content atau substance itu dengan permainan catur.

3. Langue (bahasa) dan parole (tuturan/ujaran)

Langue adalah sistem pembedaan diantara tanda-tanda sedangkan parole merupakan ekspresi kebahasaan. Dalam pengertian umum, "langue" adalah abstraksi dan artikulasi bahasa pada tingkat sosial budayanya, sedangkan "parole" merupakan ekspresi bahawa pada 
tingkat individu. Langage adalah gabungan antara parole dan langue (gabungan antara peristiwa dengan kaidah bahasa atau tata bahasa, atau struktur bahasa). Menurut Saussure, langue tidak memenuhi syarat sebagai fakta sosial karena didalam langage ada faktor-faktor bahasa individu yang berasal dari pribadi penutur sedangkan parole pemakaian suatu relasi langue oleh masing-masing anggota masyarakat bahasa yang bersifat konkret karena realitas fisis yang berbeda dari orang satu dengan orang lain.

4. Synchronic (sinkronik) dan diachronic (diakronik)

Synchronic adalah studi bahasa yang bertetapan dengan waktu penggunaanya sedangkan diachronic merupakan suatu bahasa. Kedua istilah ini berasal dari bahasa yunani khrono (waktu) dan dua awalan syn- dan dia- masingmasing berarti "bersama" dan "melalui". Ferdinand De Saussure membedakan telaah bahasa secara sinkronik dan diakronik. Telaah bahasa secara sinkronik adalah mempelajari bahasa pada waktu kurun tertentu saja.

5. Syntagmatic (sintagmatik) dan associative (paradigmatik)

Syntagmatic adalah kumpulan tanda yang berurut secara logis sedangkan associative merupakan kumpulan tanda yang dapat saling menggantikan. Hubungan keduanya dapat dinyatakan terdapat pada kata-kata sebagai rangkaian bunyi-bunyi ataupun kata-kata sebagai konsep. Konsep sintagmatik dan paradigmatik adalah konsep analisis ilmu bahasa struktural yang mengandung pengertian bahwa kemunculan suatu unsur menjadi unit selalu dalam hubungan atau relasi antara unit dengan unit maupun dengan unsur lainnya. Saussure membedakan dan tipe relasi atau hubungan, yakni relasi sintagmatik dan relasi asosiatif (yang sekarang lebih dikenal dengan istilah hubungan paradigmatik).

\section{Lirik Lagu}

Lirik lagu merupakan simbol verbal yang diciptakan oleh manusia. Manusia adalah makhluk yang tahu bagaimana harus bereaksi, tidak hanya terhadap lingkungan fisiknya, namun juga pada simbol-simbol yang dibuatnya sendiri. (Rivers, 2003). The lyrics is the commonest, and yet, in its perfection, the post modern; the simplest, and yet in its laws emotional association; and it all these because it express, more intimately, than other types of verse the personality of the poet. (Hubbel, 1949). The lyric, then, give us idea and theme and calls up 
appropriate pictures in language, wich is rich in suggestions, pictorial power, an sensuous beauty (Hubbel, 1949).

Dapat diartikan lirik, membangun persepsi serta menggambarkan sesuatu yang kemudian diperkaya akan perasaan, kekuatan imaji, serta kesan keindahan. Dalam membuat lirik lagu terkait dengan bahasa, dan bahasa terkait dengan sastra. Karena kata-kata (lirik lagu) yang dibuat oleh pencipta lagu tidak semua dapat dimengerti oleh khalayak, karena itulah memerlukan suatu penelitian tentang isi lirik lagu tersebut. Pengertian dari sastra ialah "struktur tanda-tanda yang bermakna, tanpa memperhatikan sistem tanda-tanda, dan maknanya, serta konvensi tanda, strukturkarya sastra (atau karya sastra) tidak dapat dimengerti secara optimal". (Sobur,2003).

\section{Desain Penelitian}

Pendekatan penelitian adalah kualitatif, adapun penelitian dijabarkan secara deskriptif dengan menggunakan referensi ilmiah yang sesuai dengan penelitian sejenis. Penelitian ini menggunakan metode analisis semiotika, yaitu metode yang menganalisis tentang tanda.

\section{Unit Analisis}

Penelitian ini berupa analisis semiotika, unit analisis yang digunakan adalah objek kajian yang akan dianalisis, yaitu syair lagu Aut Boi Nian, fokus dalam penelitian ini adalah pemaknaan dalam syair dalam lagu Aut Boi Nian yang dijadikan objek kajian dalam penelitian.

\section{Bahan Penelitian}

Bahan penelitian yang digunakan dalam penelitian ini adalah teks yang berupa Syair lagu Aut Boi Nian.

\section{Teknik Analisis Data}

Analisis data dalam penelitian ini dimulai dengan mengklasifikasikan lirik lagu andung saur matua maho inang yang sesuai dengan rumusan masalah penelitian. Kemudian, tahapan analisis data dapat diketahui maknanya dari lagu tersebut melalui signifier and signified, form and content, langue and parole, syncronic and diacronic, syntagmatic and associative. (Moleong, 2009).

\section{HASIL DAN PEMBAHASAN}

\section{Profil Penyanyi Viky Sianipar}

Viky Sianipar merupakan salah seorang musisi Batak modern yang disukai dari berbagai kalangan, hal ini dikarenakan kemahirannya dalam memainkan berbagai alat musik modern dan tradisional Batak yang kemudian sebagian besar lagu Batak diaransemen secara modern tanpa 
menghilangkan nuansa Bataknya sehingga kaum muda tidak malu jika mendengarkan berbagai lagu Batak. Karirnya sebagai musisi pada tahun 2002, namun dari usia enam tahun Viky sudah memulai belajar musik dan menguasai semua jenis alat musik modern dan tradisional. Sejumlah album bernuansa etnik telah dihasilkan, seperti: Toba Dream, Toba Dream 2, Toba Dream 3, dan Indonesian Beauty.

Komitmen besar untuk terus mengembangkan musik tradisional Tanah Air membuat Viky aktif bekerja sama dengan musisi dari aneka etnis, seperti Sunda, Jawa, dan Melayu. Dia juga mendirikan Viky Sianipar Music Center sebagai tempat pengembangan musik tradisional Tanah Air. Berkat kerja keras Vicky Sianipar bersama tim Pada beberapa hari lalu, Anugerah Musik Indonesia (AMI) yang ke-18, Viky Sianipar sukses sebagai pemenang pada kategori "Karya Produksi Lagu Berbahasa Daerah Terbaik". AMI Awards tahun ini bertemakan "Stop Pembajakan", ajang ini dihelat di Ecovention, Kota Ancol dan tayang secara live di RCTI.

Dari 10 kategori, Viky Sianipar masuk ke dalam nominasi: Karya Produksi Reggae/Ska/Rock Steady Terbaik, Karya Produksi Lagu Berbahasa Daerah Terbaik, Bidang Penunjang Produksi - Peramu
Rekam Terbaik. Namun dari 3 nominasi di atas, Viky Sianipar sukses sebagai pemenang pada kategori "Karya Produksi Lagu Berbahasa Daerah Terbaik”. Salah satu hasil aransemen dari Viky Sianipar adalah lah Aut Boi Nian.

\section{Aut boi nian tardungdung au}

Seandainya terjangkau tanganku

Si rumondang bulan tula $i$

Sinar bulan purnama

Putikhononhu hasian jala bahenonhu ma di podomanmi

Kan kupetik untukmu sayang lalu kuletakkan diperaduanmu

Asa sonang roham

Agar hatimu senang

Aut boi nian tarbahen au songon si doli tinodo mi

Andai bisa ku penuhi sebagai lelaki yang telah kau pilih

Satokkin on do au ro

Seketika aku akan datang

Pasahatonhu ma holong na di rohakon tu hona uli na lagu

Untuk mengunggkapkan kasih sayangku padamu yang sungguh kukasih.

Reff:

Hape ndang boi tarbahen au songon sidoli tinodo ni rohami

Ternyata tak dapat kupenuhi, seperti dia yang kau dambakan

\section{Hasian}

Sayang

Ditadinghon ho sasada au

Kau tinggalkan aku sendiri

Alani pogos ni damang dainang $i$ mambahen ingkon marsirang au Sian ho Karena kemiskinan orangtuaku membuat kita harus berpisah dengan kamu

\section{Hansit nai dangol nai sitaononhon}

Betapa pedih alangkah sengsaranya yang kualami

\section{Alani holonghi tu ho}

Karena cintaku padamu 
Dalam lagu ini menceritakan tentang sepasang kekasih yang berbeda status ekonomi, agama dan suku menjalin kasih, namun tidak mendapatkan restu dikarenakan perbedaan tersebut. Dengan berbagai perjuangan yang dilakukan oleh si lelaki berharap si perempuan dan keluarga perempuan tersebut menunggunya dan memberikan kesempatan bagi dirinya untuk menikahi perempuan itu. Namun karena si perempuan terlalu lama menunggu kehadiran si lelaki akirnya menikah dengan lelaki lain yang sesuai dengan keinginan dari orangtuanya yang status ekonominya setara dengan perempuan tersebut. Hingga suatu saat silelaki tersebut datang berkeinginan untuk melamar siperempuan karena merasa sudah memiliki apa yang diharapkan oleh si perempuan, namun apa yang didapatkan perempuan tersebut sudah memiliki suami.

$$
\text { Lelaki tersebut sangat kaget }
$$
melihat kenyataan bahwa yang diharapkan sudah menikah dengan lelaki lain, dia merasa sangat sedih dan sangat terpukul dengan kejadian tersebut sehingga dia menyalahkan dirinya atas perbuatan tersebut, namun jodoh berkata lain sehingga mereka diizinkan untuk dipertemukan sebagai sepasang suami istri. Dalam lagu ini peneliti akan menganalisis lirik lagu tersebut menggunakan teori semiotika dari Ferdinand De Saussure 


\section{Hasil Penelitian}

Hasil Penelitian Analisis Penanda dan Petanda lirik lagu

Tabel 1.

Analisis Penanda dan Petanda Lirik Pertama

\begin{tabular}{|c|c|c|}
\hline $\begin{array}{c}\text { Aspek } \\
\text { Penanda }\end{array}$ & $\begin{array}{c}\text { Tafsiran } \\
\text { seutuhnya }\end{array}$ & Aspek Petanda \\
\hline $\begin{array}{c}\text { Aut boi nian } \\
\text { tardungdung } \\
\qquad a u\end{array}$ & $\begin{array}{c}\text { Seandainya } \\
\text { terjangkau } \\
\text { tanganku }\end{array}$ & $\begin{array}{l}\text { Pada lirik pertama dalam lagu Aut Boi Nian, mengatakan } \\
\text { bahwa apapun juga yang diinginkan akan dilakukan untuk } \\
\text { kekasih hatinya, sekalipun melakukan sesuatu yang tidak } \\
\text { mungkin akan diusahakan untuk memenuhi keinginan kekasih } \\
\text { hatinya. Hal ini menunjukkan pengorbanannya kepada } \\
\text { kekasih hatinya untuk memberikan sesuatu yang terbaik. } \\
\text { Makna Tardungdung au menunjukkan makna bahwa sesuatu } \\
\text { yang memang bisa untuk dilakukan akan dilakukannya untuk } \\
\text { menyenangkan hati kekasihnya. } \\
\text { Kata tardungdung au menunjukkan segala sesuatu hal apapun } \\
\text { akan dilakukan untuk seseorang yang dikasihinya ini } \\
\text { membuktikan bahwa dia sangat mencintai kekasihnya. Tanda } \\
\text { pengorbanan yang dilakukan untuk pasangannya. }\end{array}$ \\
\hline
\end{tabular}

Aspek Signifikasi

Kata “tardungdung au” yang dimaksudkan bagi masyarakat Batak toba disini ialah melakuan sesuatu hal dengan sungguh-sungguh dengan keseriusan kepada seseorang karena rasa suka dan cinta yang mendalam. Bagi masyarakat Batak jika sebasang kekasih mengatakan tardungdung au ini menunjukkan keseriusan dalam melakukan tindakan seseorang kepada pasangannya. Hal ini biasa dilakukan pasangan kekasih jika benar-benar saling mencintai. Bahkan melakukan sesuatu hal yang tidak mungkin juga akan dilakukan untuk menunjukkan rasa sayangnya terhadap kekasihnya.

$$
\text { Bagi masyarakat Batak kata }
$$
tardungdung au ini menegaskan bahwa kegiatan yang hanya bisa dilakukan oleh seseorang yang sangat mencintai orang lain. Kata ini biasa digunakan untuk orang yang sedang dimabuk cinta yang selalu merasakan kebahagiaan dan kesenangan untuk melakukan apapun juga untuk pasangannya. Pengorbanan yang diberikan kepada pasangannya sebagai tanda cintanya kepada pasangannya. 
Tabel 2. Aspek Penanda dan Petanda Lirik Kedua

\begin{tabular}{|c|c|c|}
\hline $\begin{array}{c}\text { Aspek } \\
\text { Penanda }\end{array}$ & $\begin{array}{c}\text { Tafsiran } \\
\text { Seutuhnya }\end{array}$ & Aspek Petanda \\
\hline $\begin{array}{c}\text { Si } \\
\text { rumondang } \\
\text { bulan tula } i\end{array}$ & $\begin{array}{c}\text { Sinar bulan } \\
\text { purnama }\end{array}$ & $\begin{array}{l}\text { Pada lirik kedua ini menceritakan tentang sinar bulan } \\
\text { purnama, hal ini menunjukkan sesuatu yang sangat indah, } \\
\text { sangat cemerlang, sangat terang yang akan diberikannya untuk } \\
\text { kekasih hatinya. Sinar yang tidak akan mungkin digapainya } \\
\text { akan tetap diberikan kepada kekasih hatinya untuk menerangi } \\
\text { kekasihnya. Makna rumondang merupakan makna yang } \\
\text { memancarkan cahaya dan bergemilang. Memberikan pancaran } \\
\text { sinar yang sangat indah untuk kekasih hatinya. } \\
\text { Tidak hanya masyarakat Batak saja yang menganalogikan } \\
\text { sinar merupakan sesuatu yang bagus dan bersinar namun } \\
\text { semua masyarakat memaknai sinar sebagai sesuatu yang } \\
\text { gemerlapan. Sinar bulan purnama menunjukkan sesuatu yang } \\
\text { sangat indah yang akan diberikan kepada pasangannya sebagai } \\
\text { bukti cintanya kepada pasangannya. }\end{array}$ \\
\hline
\end{tabular}

yang akan diberikan susah untuk

\section{Aspek Signifikansi}

Kata Rumondang dalam syair
disini menunjukkan sinar yang
gemerlapan. Rumondang bulan tula I
mengisahkan memberikan sesuatu yang
terbaik untuk kekasih hatinya. Walaupun
untuk mendapatkan sinar tersebut tidak
akan mungkin terjadi. Namun ini
menunjukkan sebuah kiasan bahwa yang
terbaik yang bersinar akan diberikan
kepada kekasih hatinya walaupun sesuatu

diraihnya. Sinar yang mampu memberikan gemerlap cahaya yang akan memberikan ketenangan bagi kekasihnya yang tidak berada didekatnya. Sinar bulan purnama merupakan analogi yang digunakan dalam syair ini untuk menunjukkan sesuatu yang indah yang akan diberikan kepada pasangannya dan inilah yang disebut sebagai perbuatan cinta yang dilakukan oleh seseorang yang benar-benar mengasihinya. 
Tabel 3. Aspek Penanda dan Petanda Lirik Ketiga

\begin{tabular}{|c|c|c|}
\hline $\begin{array}{c}\text { Aspek } \\
\text { Penanda }\end{array}$ & $\begin{array}{c}\text { Tafsiran } \\
\text { Seutuhnya }\end{array}$ & Aspek Petanda \\
\hline $\begin{array}{l}\text { Putikhononhu } \\
\text { hasian Jala } \\
\text { bahenonhu } \\
\text { ma di } \\
\text { podomanmi }\end{array}$ & $\begin{array}{l}\text { Kan kupetik } \\
\text { untukmu } \\
\text { sayang } \\
\text { Lalu } \\
\text { kuletakkan } \\
\text { diperaduanmu }\end{array}$ & $\begin{array}{l}\text { Mengambil sinar yang terang dan gemerlapan, dan sinar } \\
\text { tersebut diberikan kepada kekasih hatinya. Makna yang } \\
\text { tersirat menunjukkan bahwa sesuatu hal akan dicari dan } \\
\text { akan diberikan kepada kekasih hatinya, hal ini } \\
\text { menunjukkan rasa sayang dan cintanya kepada sang } \\
\text { kekasihnya untuk menemanin kekasihnya didalam hari saat } \\
\text { sedang terbaring tidur sehingga tidak mengalami kesepian, } \\
\text { namun diterangi oleh sinar bulan disaat malam datang. } \\
\text { Sehingga dalam istirahatnya ditemani oleh sinar bulan yang } \\
\text { sangat indah, tidak akan mengalami kesepian dimalam hari } \\
\text { karena ditemani oleh terangnya sinar bulan. }\end{array}$ \\
\hline
\end{tabular}

\section{Aspek Signifikansi}

Kata Putikhononhu hasian menggambarkan bahasa kiasan untuk mencari sesuatu sampai dan harus dapat setelah itu memberikan kepada orang yang disayanginya. Memberikan sesuatu yang diinginkan oleh kekasihnya sebagai ungkapan bahwa benar-benar menyanyanginya. Mengikuti semua yang diinginkan oleh kekasihnya. Dan meletakkan ditempat tidurnya untuk menemanin malam yang gelap. Sinar yang gemerlap mampu membuang rasa takut karena kegelapan dimalam hari. Ini menunjukkan bahwa sinar bulan yang akan menemaninya tidur menggantikan dirinya, sehingga malam yang dilewati menjadi bersinar dan terang. Sesuatu yang bersinar yang akan menerangi dan menemani istirahat di malam harinya sehingga malam itu menjadi sangat indah untuk dilewatin oleh pasangannya dan juga merasakan kenyamanan dalam mimpi yang indah. 
Tabel 4. Aspek Penanda dan Petanda Lirik Keempat

\begin{tabular}{|c|c|l|}
\hline $\begin{array}{c}\text { Aspek } \\
\text { Penanda }\end{array}$ & $\begin{array}{c}\text { Tafsiran } \\
\text { Seutuhnya }\end{array}$ & \multicolumn{1}{|c|}{ Aspek Petanda } \\
\hline $\begin{array}{c}\text { Asa sonang } \\
\text { roham }\end{array}$ & $\begin{array}{c}\text { Agar } \\
\text { hatimu } \\
\text { senang }\end{array}$ & $\begin{array}{l}\text { Pada lirik sonang menunjukkan kebahagiaan yang tidak } \\
\text { terhingga. Senang yang dirasakan dihati dan senang yang } \\
\text { diberikan oleh kekasih hatinya. Rasa senang menggambarkan } \\
\text { dari kebahagiaannya karena sesuatu yang diinginkan telah } \\
\text { didapatinya dan diberikan oleh orang yang dikasihinya. Selalu } \\
\text { memberikan yang terbaik untuk pasangannya agar } \\
\text { pasangannya selalu merasakan kebahagiaan. }\end{array}$ \\
\hline
\end{tabular}

\section{Aspek Signifikansi}

Pada lirik ini "asa sonang roham" menceritakan bahwa silelaki telah mencari sesuatu yang sulit didapatkan dan yang diingikan oleh kekasih hatinya dan memberikannya kepada kekasihnya. Sinarnya bulan yang sulit digapai seolah sudah didapatinya dan ditempatkan ditempat tidurnya untuk menemani malam yang gelap sehingga tidak mengalami ketakutan melainkan menemukan rasa terang dan nyaman. Semua yang diinginkan oleh kekasihnya merupakan suatu kewajiban dan sudah dipenuhi untuk memberikan semua ini atas dasar perbuatan cinta. Semua dilakukannya agar hati pasangannya menjadi bahagia karena telah menurutin semua yang diinginkan. Kesenangan yang dialami oleh pasangannya merupakan kesenangan yang juga dirasakannya. 
Tabel 5. Aspek Penanda dan Petanda Lirik Kelima

\begin{tabular}{|c|c|c|}
\hline $\begin{array}{c}\text { Aspek } \\
\text { Penanda }\end{array}$ & $\begin{array}{c}\text { Tafsiran } \\
\text { Seutuhnya }\end{array}$ & Aspek Petanda \\
\hline $\begin{array}{c}\text { Aut boi nian } \\
\text { tarbahen au } \\
\text { Songon si } \\
\text { doli tinodo } \\
\text { mi }\end{array}$ & $\begin{array}{l}\text { Andai bisa ku } \\
\text { penuhi } \\
\text { Sebagai lelaki } \\
\text { yang telah kau } \\
\text { pilih }\end{array}$ & $\begin{array}{l}\text { Pada lirik ini menunjukkan bahwa keinginan seorang laki- } \\
\text { laki untuk dapat membahagiakan pasangannya, memenuhi } \\
\text { segala keinginannya dan menunjukkan bahwa mampu } \\
\text { menjadi lelaki yang bisa membuat bahagia. Hal ini } \\
\text { dilakukannya untuk menunjukkan bahwa pasangannya } \\
\text { tersebut nantinya tidak salah memilih dirinya untuk dapat } \\
\text { memberikan kebahagiaan dalam kehidupan berumah } \\
\text { tangga. Semua permintaannya akan dipenuhi untuk } \\
\text { memberikan rasa senang di hati kekasihnya. Ini } \\
\text { menunjukkan bahwa saat saya dipilih menjadi lelaki } \\
\text { pilihannya semua hal akan dipenuhi untuk menciptakan } \\
\text { kebahagiaan bagi kekasihnya. }\end{array}$ \\
\hline
\end{tabular}

\section{Aspek Signifikansi}

Makna "Songon sidoli tinodomi" menunjukkan bahwa sebagai lelaki yang dipilih akan melakukan apa saja untuk membuat kebahagiaan dihati kekasihnya. Ini menunjukkan bahwa dia bersedia untuk menjadi lelaki yang bertanggung jawab untuk memberikan perlindungan dan kebahagiaan bagi pasangannya. Tidak hanya masyarakat Batak saja namun lelaki harus bertanggung jawab untuk memberikan kebahagiaan bagi pasangannya. Kalimat ini menunjukkan kesiapan seorang laki-laki yang telah dipilih untuk dapat bertanggungjawab kepada kekasihnya didalam segala hal baik dalam kasih sayang, mencukupi kebutuhan hidupnya, memberikan rasa nyaman dan yang lainnya.
Lelaki yang seperti itulah yang akan selalu diinginkan oleh setiap perempuan. Kebanggaan bagi seorang wanita jika mendapatkan lelaki yang bertanggungjawab dan selalu berusaha untuk memberikan rasa kebahagiaan dan kenyamanan bagi pasangannya. 
Tabel 6. Aspek Penanda dan Petanda Lirik Keenam

\begin{tabular}{|c|c|l|}
\hline $\begin{array}{c}\text { Aspek } \\
\text { Penanda }\end{array}$ & $\begin{array}{c}\text { Tafsiran } \\
\text { Seutuhnya }\end{array}$ & \multicolumn{1}{|c|}{ Aspek Petanda } \\
\hline $\begin{array}{c}\text { Satokkin on } \\
\text { do au ro }\end{array}$ & $\begin{array}{c}\text { Seketika } \\
\text { aku akan } \\
\text { datang }\end{array}$ & $\begin{array}{l}\text { Pada lirik ini menunjukkan bahwa untuk memenuhi semua } \\
\text { keinginan kekasihnya tidak dalam waktu singkat untuk } \\
\text { memperolehnya, namun memakai proses untuk membuktikan } \\
\text { semua rasa cintanya kepada kekasih hatinya. Sehingga } \\
\text { meminta waktu untuk dapat mewujudkan semua } \\
\text { permintaannya. Makna Satokkin menunjukkan waktu yang } \\
\text { singkat. Walaupun harus melewati waktu dan proses yang } \\
\text { panjang untuk mendatangi kekasihnya kembali. }\end{array}$ \\
\hline
\end{tabular}

\section{Aspek Signifikansi}

Makna dari satokkin on do au ro disini adalah meminta waktu untuk menunggunya. Menunggu tidak akan terasa lama jika didasari rasa cinta yang medalam. Meminta waktu untk menunggu disini karena ingin membahagiakan kekasihnya dengan cara bekerja keras untuk memenuhi keinginan kekasihnya. Perkataan seketika disini menunjukkan waktu yang harus dikorbankan untuk menunggu dirinya berkomitmen tidak untuk meninggalkannya. Satokkin disini mengatakan waktu yang sebentar untuk menunggu saya sampai saya bisa mewujudkan apa yang diinginkan.

Yang diharapkan dari perkataan ini adalah jika benar-benar kekasihnya menyayanginya dan berharap pada dirinya saja akan tetap menunggunya tanpa ada asalan apapun untuk meninggalkannya sampai dia datang kembali untuk menjemputnya dan membuktikannya bahwa dia benar-benar berusaha membuat bahagia dan memenuhi keinginan pasangannya. 
Tabel 7. Aspek Penanda dan Petanda Lirik Ketujuh

\begin{tabular}{|c|c|l|c|}
\hline $\begin{array}{c}\text { Aspek } \\
\text { Penanda }\end{array}$ & $\begin{array}{c}\text { Tafsiran } \\
\text { Seutuhnya }\end{array}$ & \multicolumn{2}{|c|}{ Aspek Petanda } \\
\hline $\begin{array}{c}\text { Pasahatonhu } \\
\text { ma holong }\end{array}$ & Untuk & Makna yang terdapat dalam lagu ini menunjukkan bahwa \\
ma di & apkan kasih & penkataan saja namu juga melalui bukti untuk \\
rohakon $\boldsymbol{T u}$ & sayangku & bertanggungjawab kepada kekasihnya. Ungkapan kasih sayang \\
hona $\boldsymbol{u l i} \boldsymbol{n a}$ & Padamu & yang diberikan merupakan harus dapat membuat kekasihnya \\
lagu & yang & menjadi bahagia. Ketulusan cintanya pada pasangannya \\
& sungguh & dengan cara menunjukkan keseriusannya dalam memenuhi \\
& kukasih & segala kebutuhan dan keinginan dari pasangannya. \\
\hline
\end{tabular}

\section{Aspek Signifikansi}

Makna yang terkandung dari pasahuton hu merupakan maka yang ingin mengucapkan sesuatu hal dengan cara yang tulus untuk kekasih hatinya. Tidak hanya rasa sayang dan perhatian saja yang dibutuhkan namun juga perbuatan yang melindungi kekasih hatinya. Keinginan yang harus dipenuhi tidak hanya keinginan dari kekasihnya namun juga keinginan dari keluarga besar dari kekasihnya agar hubungan tersebut diyakini dapat berjalan dengan baik atas restu dari pihak keluarga besar. Dimana sebuah hubungan yang serius tidak hanya melibatkan sepasang laki-laki dan perempuan. Ada orang tua dan keluarga besar yang sepatutnya memang dilibatkan dalam hubungan yang akan dijalani. Di saat inilah sebenarnya kami merasakan kebanggaan yang luar biasa. Momen dimana kami merasa benar- benar dihargai dan cintai. Karena inilah pertanda keseriusan dalam sebuah hubungan yang dijalani oleh sepasang kekasih. 
Tabel 8. Aspek Penanda dan Petanda Lirik Kedelapan

\begin{tabular}{|c|c|l|}
\hline $\begin{array}{c}\text { Aspek } \\
\text { Penanda }\end{array}$ & $\begin{array}{c}\text { Tafsiran } \\
\text { Seutuhnya }\end{array}$ & \multicolumn{2}{|c|}{ Aspek Petanda } \\
\hline $\begin{array}{c}\text { Hape ndang } \\
\text { boi tarbahen }\end{array}$ & Ternyata & Makna yang terdapat dalam lirik ini menunjukkan bahwa \\
tau Songon & kupenuhi, & ketidakmampuannya untuk memenuhi keinginan dari pihak \\
sidoli tinodo & Seperti dia & harus dipenuhi adalah menjadi seorang suami yang memiliki \\
ni rohami & yang kau & pekerjaan yang mapan dan perekonomian yang baik. Namun \\
& dambakan & sampai saat yang ditentukan lelaki ini belum dapat \\
& & menunjukkan kesanggupannya untuk memenuhi yang \\
& & diinginkan oleh pihak keluarga perempuan. Ada kepasrahan \\
& yang terlihat seperti tidak memiliki harapan lagi untuk dapat \\
& hidup bersama. \\
\hline
\end{tabular}

Aspek Signifikansi

Makna dari kata "ndang boi tarbahen au" menjukkan ketidaksanggupannya dalam memenuhi keinginan dari pihak keluarga perempuan. Ketidaksanggupan ini dari berbagai aspek yang diharapkan seperti pekerjaan yang mapan, memiliki kebutuhan dasar dalam berumahtangga dan yang terpenting menunjukkan kesiapan dalam memberikan kebahagiaan dari sisi materi untuk kelangsungan hidup berumah tangga nantinya. Bahwa sebuah hubungan yang serius memang layak diketahui mereka yang punya peranan penting dalam hidup yaitu orang tua dan keluarga besar, namun momen seperti ini seringkali yang menjadi ditakutkan oleh banyak pihak jika keinginan dari salah satu pihak keluarga tidak sesuai dengan yang diharapkan akan mendapatkan konsekuensi yang sangat merugikan salah satu pihak. 
Tabel 9. Aspek Penanda dan Petanda Lirik Kesembilan

\begin{tabular}{|c|c|c|}
\hline $\begin{array}{c}\text { Aspek } \\
\text { Penanda }\end{array}$ & $\begin{array}{c}\text { Tafsiran } \\
\text { Seutuhnya }\end{array}$ & Aspek Petanda \\
\hline Hasian & Sayang & $\begin{array}{l}\text { Makna yang terdapat dalam lirik ini menunjukkan bahwa } \\
\text { orang yang benar-benar disayang yang ada didalam hatinya. } \\
\text { Ungkapan kata hasian ini dikhususkan untuk seseorang yang } \\
\text { disayanginnya. Seperti panggilan untuk pacar atau untuk } \\
\text { istri/suami, sehingga kata Hasian ini dikhususkan hanya untuk } \\
\text { seseorang. }\end{array}$ \\
\hline
\end{tabular}

Aspek Signifikansi

Makna dari kata Hasian ini untuk menyebut seseorang yang disayangi dan dicintai nya. Panggilan ini dalam kebiasaan orang batak menunjukkan panggilan yang sangat hangat dan dekat kepada orang yang disayanginnya. sering diucapkan oleh orang batak, Terutama mereka yang sedang menjalin sebuah hubungan atau pacaran, selain itu juga kata hasian juga bisa dipakai oleh orang tua memanggil atau menyebutkan kepada anaknya yang dikasihinya. Namun kata hasian seringkali digunakan untuk orang yang berpacaran untuk merayu seseorang. Lelaki ini menyebut wanita yang disayanginnya dengan kata hasian, ini menunjukkan rasa sayangnya terhadap orang yang disayanginnya. 
Tabel 10. Aspek Penanda dan Petanda Lirik Kesepuluh

\begin{tabular}{|c|c|l|c|}
\hline $\begin{array}{c}\text { Aspek } \\
\text { Penanda }\end{array}$ & $\begin{array}{c}\text { Tafsiran } \\
\text { Seutuhnya }\end{array}$ & \multicolumn{3}{|c|}{ Aspek Petanda } \\
\hline $\begin{array}{c}\text { Ditadinghon } \\
\text { ho sasada au }\end{array}$ & $\begin{array}{c}\text { Kau } \\
\text { tinggalkan } \\
\text { aku sendiri }\end{array}$ & $\begin{array}{l}\text { Makna yang terdapat dalam lirik ini menunjukkan bahwa } \\
\text { keputusannya untuk meninggalkannya karena tidak sesuai } \\
\text { yang diharapkan oleh pihak perempuan. Hal ini } \\
\text { mengakibatkan kehilangan orang yang disayanginya dan } \\
\text { tinggal seorang diri. Hal ini menunjukkan bahwa perempuan } \\
\end{array}$ & $\begin{array}{l}\text { ini lebih memilih orang tuanya dan meninggalkan lelaki } \\
\text { tersebut seorang diri, karena dianggap tidak sanggup } \\
\text { memenuhi keinginan dari orangtua pihak perempuan. }\end{array}$ \\
\hline
\end{tabular}

\section{Aspek Signifikan}

Makna dari kata ditadinghon ho sasada au ini menunjukkan bahwa kesedihan yang benar-benar dirasakan oleh lelaki karena perempuan yang disayangi dan dicintainya lebih memilih keluarga dan meninggalkan lelaki tersebut. Ini menunjukkan bahwa kehancuran yang dirasakan oleh lelaki tersebut sehingga membuat dia menjadi seorang diri dan putus harapan. Dalam kata ini memberikan makna bahwa tidak ada harapan untuk bersama lagi, karena orang yang disayanginya memilih keluarganya dan tidak memilih dirinya, sehingga dirinya hanya tinggal seorang diri tanpa ada kepastian untuk dapat bersama lagi. Ini menunjukkan suatu keputusasaan bagi seseorang karena cintanya tidak berbalas seperti yang diharapkan. Rasa hancur yang tidak dapat dilukiskan seperti apapun karena ditinggalkan oleh orang yang disayanginnya. 
Tabel 11. Aspek Penanda dan Petanda Lirik Kesebelas

\begin{tabular}{|c|c|l|}
\hline $\begin{array}{c}\text { Aspek } \\
\text { Penanda }\end{array}$ & $\begin{array}{c}\text { Tafsiran } \\
\text { Seutuhnya }\end{array}$ & \multicolumn{1}{|c|}{ Aspek Petanda } \\
\hline $\begin{array}{c}\text { Alani pogos } \\
\text { ni damang } \\
\text { dainang I }\end{array}$ & $\begin{array}{c}\text { Karena } \\
\text { Kemiskinan } \\
\text { Orangtuaku } \\
\text { Mambahen } \\
\text { ingkon } \\
\text { marsirang }\end{array}$ & $\begin{array}{l}\text { Makna yang terdapat dalam lirik ini menunjukkan bahwa } \\
\text { dirinya ditinggalin oleh kekasih hatinya dikarenakan } \\
\text { orangtuanya tidak memiliki perekonomian yang baik } \\
\text { seperti yang diharapkan oleh keluarga perempuan. }\end{array}$ \\
$\begin{array}{c}\text { au Sian ho } \text { harus berpisah } \\
\text { dengan kamu }\end{array}$ & $\begin{array}{l}\text { Kemiskinan membuat mereka harus berpisah. Kata cinta } \\
\text { saja tidak mampu untuk menyatukan mereka dikarenakan } \\
\text { tidak dibarengin oleh permintaan dari pihak keluarga } \\
\text { perempuan. Karena dianggap tidak akan bisa membuat } \\
\text { bahagia dan nyaman jika tidak memiliki perekonomian } \\
\text { yang baik. }\end{array}$ \\
\hline
\end{tabular}

\section{Aspek Signifikan}

Makna dari kata alani pogos ni damang dainang $i$ ini menunjukkan bahwa karena kemiskinan orangtuaku membuat mereka harus berpisah. Perekonomian terkadang dijadikan alasan untuk tidak dapat bersatu dalam ikatan pernikahan. Perekonomian yang tidak baik membuat mereka harus berpisah. Banyak kasus yang terjadi menunjukkan bahwa perekonomian menjadi alasan utama dalam membangun rumah tangga, sehingga jika perekonomian tidak sesuai yang diharapkan dapat menjadi masalah dan alasan untuk berpisah. Ketidaksetaraan status sosial ekonomi dalam hubungan yang serius seringkali mengalami kendala dan berakir pada kata berpisah. Kesakitan yang dirasakan dikarenakan perekonomian keluarga lelakinya tidak seimbang dengan perekonomian dari pihak perempuan sehingga mereka harus berpisah dan pihak lelaki mengalami kesakitan hati karena dianggap tidak mampu memberikan rasa bahagia bagi pasangannya. 
Tabel 12. Aspek Penanda dan Petanda Lirik Keduabelas

\begin{tabular}{|c|c|c|}
\hline $\begin{array}{c}\text { Aspek } \\
\text { Penanda }\end{array}$ & $\begin{array}{c}\text { Tafsiran } \\
\text { Seutuhnya }\end{array}$ & Aspek Petanda \\
\hline $\begin{array}{c}\text { Hansit nai } \\
\text { dangol nai } \\
\text { sitaononhon }\end{array}$ & $\begin{array}{c}\text { Betapa } \\
\text { pedih } \\
\text { alangkah } \\
\text { sengsaranya } \\
\text { yang } \\
\text { kualami }\end{array}$ & $\begin{array}{l}\text { Makna yang terdapat dalam lirik ini menunjukkan bahwa } \\
\text { kesengsaraan yang dialami oleh lelaki tersebut dikarenakan } \\
\text { ditinggalkan oleh perempuan tersebut. Sangat sengsara yang } \\
\text { dirasakan karena perempuan tersebut tidak berpihak pada nya. } \\
\text { Rasa sakit dan sengsara yang dirasakannya karena kejadian } \\
\text { ini. Rasa sengsara seperti ini yang seringkali tidak kuat } \\
\text { dijalani oleh seseorang. Karena cintana hanya bertepuk } \\
\text { sebelah tangan saja. }\end{array}$ \\
\hline
\end{tabular}

\section{Aspek Signifikan}

Makna signifikan dari kata "Hansit Nai" merupakan ungkapan rasa sakit yang benar-benar sakit dirasakannya karena masalah ini. Sakit yang tidak dapat terlukiskan oleh dirinya karena benarbenar menderita merasakan sakit ini. Sakit yang diakibatkan oleh penolakan cintanya oleh calon keluarga perempuan. Sebuah hubungan tidak melulu bisa berjalan mulus. Ada saat dimana pasangan harus bertengkar lantaran berselisih paham atau berbeda pendapat. Di saat-saat seperti ini, pasangan seringkali tak bisa menahan emosi dan saling menyakiti.

Dimana sebuah hubungan tidak seharusnya selalu bisa berjalan baik dan mulus. Ada saat dimana pasangan harus bertengkar, berselisih paham, berbeda pendapat ataupun sesuatu yang menghalangi cinta mereka. Di saat-saat seperti ini, pasangan seringkali tidak bisa menahan emosi dan saling menyakiti baik dari tindakan maupun perkataan. Rasa sakit karena ada penghalang terhadap cinta mereka membuat sepasang kekasih tidak dapat bersatu dan ada pihak yang merasakan kesakitan dengan keadaan seperti ini. 
Tabel 13. Aspek Penanda dan Petanda Lirik Ketigabelas

\begin{tabular}{|c|c|l|}
\hline $\begin{array}{c}\text { Aspek } \\
\text { Penanda }\end{array}$ & $\begin{array}{c}\text { Tafsiran } \\
\text { Seutuhnya }\end{array}$ & \multicolumn{1}{c|}{ Aspek Petanda } \\
\hline $\begin{array}{c}\text { Alani } \\
\text { holonghi tu } \\
\text { ho }\end{array}$ & $\begin{array}{c}\text { Karena } \\
\text { cintaku } \\
\text { padamu }\end{array}$ & $\begin{array}{l}\text { Makna yang terdapat dalam lirik ini menunjukkan bahwa rasa } \\
\text { cinta yang diberikannya membuat dirinya menjadi sengsara. } \\
\text { Kesengsaraan ini dirasakannya karena perasaan cintanya tidak } \\
\text { diterima oleh perempuannya dan keluarga perempuannya. }\end{array}$ \\
\hline
\end{tabular}

\section{Aspek Signifikan}

Makna signifikan dari kata Alani holong tu ho merupakan ungkapan rasa cinta yang sangat mendalam yang diungkapkan dan diberikannya kepada perempuan tersebut namun tidak mendapatkan balasan yang sama dari pihak keluarga perempuannya sehingga rasa cinta tersebut hanya pada satu sisi saja. Setiap orang bisa melakukan apa saja demi cintanya. Cinta adalah sebuah kisah, kisah yang merefleksikan kepribadian, minat dan perasaan seseorang terhadap suatu hubungan. Kisah pada setiap orang berasal dari "skenario" yang sudah dikenalnya, apakah dari orang tua, pengalaman, cerita dan sebagainya. Kisah ini biasanya mempengaruhi orang bagaimana dia bersikap dan bertindak dalam sebuah hubungan. Namun jika cinta dan pengorbanan yang diberikan tidak dibalas sesuai yang diharapkan dapat memberikan seseorang menjadi sangat tertekan. Mencintai berarti berusaha membuat pasangan merasa aman dan terlindungi. 
Hasil Penelitian Analisis Bahasa dan Tuturan

Peneliti akan melihat apa yang menjadi bahasa dan tuturan dari lagu Aut Bonian.

Tabel 14. Bahasa dan Tuturan

\begin{tabular}{|l|l|}
\hline \multicolumn{1}{|c|}{ Bahasa } & \multicolumn{1}{|c|}{ Tuturan } \\
\hline Aut boi nian tardungdung au & Kata Hasian yang berarti Sayang \\
Si rumondang bulan tula $\boldsymbol{i}$ & atau Cinta. Dimana bagi orang \\
Putikhononhu hasian jala bahenonhu ma di podomanmi & batak untuk panggilan kata hasian \\
Asa sonang roham & selalu untuk panggilan seseorang \\
Aut boi nian tarbahen au songon si doli tinodo mi & kepada orang lain yang \\
Satokkin on do au ro & disayanginnya Seperti seorang \\
Pasahatonhu ma holong na di rohakon tu hona uli na lagu & ibu ke anaknya atau sepasang \\
Reff: & kekasih. Yang berarti kata itu \\
Hape ndang boi tarbahen au songon sidoli tinodo ni rohami & yang ditujukan panggilan untuk \\
Hasian & orang yang spesial atau yang \\
Ditadinghon ho sasada au & disayangin. Sama hal lainnya dari \\
Alani pogos ni damang dainang i mambahen ingkon & suku dan daerah lain di Indonesia \\
marsirang au Sian ho & mempunyai panggilan tersendiri \\
Hansit nai dangol nai sitaononhon & untuk memanggil seseorang yang \\
Alani holonghi tu ho & sangat disayanginnya. \\
\hline
\end{tabular}

Tuturan dari kata hasian ialah katakata yang sering kita gunakan bagi orang Batak yang sedang berbicara dengan pasangannya. Kata-kata tersebut sudah menjadi bagian dari setiap orang Batak yang bertutur atau terucap kepada orang yang sangat disayanginnya. Bisa ungkapan untuk suami atau istri bisa ungkapan untuk pacar ataupun untuk seseorang yang disayanginya. 


\section{PENUTUP}

Pada kajian ini Peneliti akan melihat apa yang menjadi sinkronik dan diakronik dari lagu "Aut Boi Nian” yang menjadi objek penelitian yang dikaji peneliti yang disimpulkan adalah .

Tabel Sinkronik dan Diakronik

\begin{tabular}{|c|c|}
\hline Sinkronik & Diakronik \\
\hline $\begin{array}{l}\text { Awal pertama kali dikenalkan lagu aut boi } \\
\text { nian dinyanyikan oleh Amigos band, lalu } \\
\text { diaransemen ulang oleh Vikcy Sianipar } \\
\text { spesial untuk film Toba dream yang } \\
\text { Movienya sudah keluar dan bisa di tonton di } \\
\text { bioskop. Lagu ini populer dimasyarakat } \\
\text { Batak saja namun juga populer di seluruh } \\
\text { kalangan. Keberhasilan film Toba Dreams } \\
\text { mengangkat lagu Aut Boi Nian menjadi lagu } \\
\text { yang sering dinyanyikan muda-mudi Batak } \\
\text { saat sedang acara formal dan informal. }\end{array}$ & $\begin{array}{l}\text { Lagu percintaan dan sudah diperbaharui } \\
\text { aransemennya mengikuti keinginan } \\
\text { masyarakat. Sehingga lagu Aut Boi Nian } \\
\text { dengan mudah untuk diterima masyarakat. } \\
\text { Lirik yang bernuansa percintaan dengan } \\
\text { aransemen yang mendukung membuat lagu } \\
\text { dengan mudahnya diterima oleh masyarakat. } \\
\text { Lagu Aut Boi Nian sering dinyanyikan pada } \\
\text { saat pesta pernikahan maupun di acara-acara } \\
\text { non formal remaja Batak. }\end{array}$ \\
\hline
\end{tabular}

Penelitian sinkronik dan diakronik adalah mempelajari bahasa dan semuanya yang berkaitan dengan waktu/zaman. Jadi dalam hal ini, kata yang digunakan dalam lagu Aut Boi Nian aransemennya lebih disesuaikan dengan keadaan pada zaman sekarang sehingga mudah untuk diterima masyarakat. Tema yang khas untuk saling mengasihi walau ada perbedaan status sosial ekonomi dari salah satu pihak menjadi alasan yang kuat untuk tetap mempertahan hubungan. Biasanya lirik

\section{Sintagmatik dan Paradigmatik}

lagu seperti ini diciptakan karena kejadian yang seperti ini sering kali terjadi dimasyarakat sehingga dituangkan dalam syair. Karena lagu Aut Boi Nian merupakan sountrack dari Toba Dreams. Kata-kata yang digunakan disesuaikan dengan selera kaula muda yang saling mengasihi dan harus terpisah karena keinginan dari orang tua yang harus dipatuhi dan mengorbankan keinginan hatinya untuk dapat bersatu dengan seseorang yang telah dipilihnya.

Peneliti akan melihat apa yang menjadi sintagmatik dan paradigmatik dari lagu Aut Boi Nian yang menjadi objek 
penelitian yang dikaji peneliti. Dalam sintakmatik dalam lagu tersebut dilihat dari not yang dibuat oleh si pencipta lagu yang nantinya akan dijadikan sebuah lagu. Sedangkan dalam paradigmatik yang terdapat dalam lagu tersebut ialah lirik lagunya yang dibuat oleh si penciptanya menjadi senada dengan sintakmatiknya yaitu not nadanya.

\section{DAFTAR PUSTAKA}

Dedy Mulyana. 2000. “ Ilmu Komunikasi, Pengantar” Bandung: Remaja Rosadakarya.

Eriyanto. 2001. Analisis Wacana, Pengantar Analisis Teks Media. Yogyakarta: LKIS.

Fiske John. 2007. Cultural and Communication Studies. Yogyakarta: Jalasutra.

Hartman. Stres dan koping mahasiswa kepribadian tipe kepribadian tipe A dan $B$ dalam menyusun skripsi fakultas keperawatan unuversitas sumatera utara tahun 2013.

Lechte John. 2001. 50 Filsuf Kontemporer. Yogyakarta: Penerbit Kanisius.

Littlejohn W. Stephen \& Foss A. Karen. 2009. "Teori Komunikasi (Theories of Human Communicationn)". Jakarta: Salemba Humanika.

Moleong JL. 2009, Metode Penelitian Kualitatif. Bandung: PT. Remaja Rosdakaya.

Piliang Y A. 2003. Hipersemiotika.Tafsir Cultural Studies atas Matinya Makna. Yogyakarta: Jalasutra.

Rachmawati Y. 2005. Musik Sebagai Pembentuk Budi Pekerti. Yogyakarta: Panduan.
Sternberg. RJ. 1987. The triangle of love: intimacy, passion, commitment. New York: Basic Books, Inc.

Suprayogo. Imam dan Tobroni. 2001. Metode Penelitian Sosial Agama. Bandung: PT. Remaja Rosda Karya.

Sugiyono. 2008. Metode Penelitian kuantitatife, Kualitatife, dan R \& D. Bandung: ALFABETA.

Sobur A. 2003. "Analisis Teks Media: Suatu Pengantar, untuk Analisis Wacana, Analisis Semiotik dan Analisis Framing”. Bandung: Remaja Rosdakarya.

Zaimar Sumantri Kusuma Okke. 2005. "Semiotika dalam Analisis Karya Sastra”. Depok: Komodo Books. 